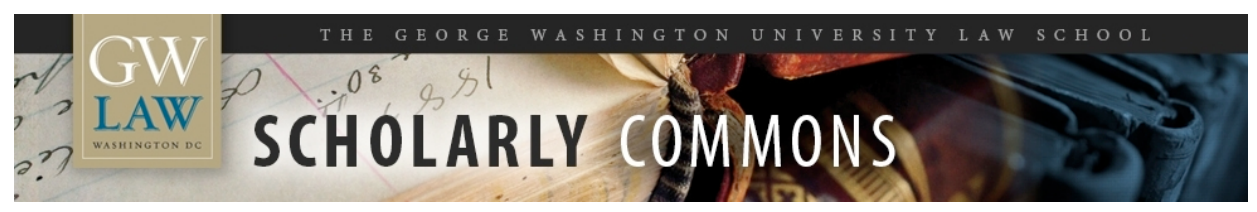

\title{
Transparency and Participation in the World Trade Organization
}

Steve Charnovitz

George Washington University Law School, scharnovitz@law.gwu.edu

Follow this and additional works at: https://scholarship.law.gwu.edu/faculty_publications

Part of the Law Commons

\section{Recommended Citation}

Steve Charnovitz, Transparency and Participation in the World Trade Organization, 56 Rutgers L. Rev. 927 (2004).

This Article is brought to you for free and open access by the Faculty Scholarship at Scholarly Commons. It has been accepted for inclusion in GW Law Faculty Publications \& Other Works by an authorized administrator of Scholarly Commons. For more information, please contact spagel@law.gwu.edu. 


\title{
Transparency AND PARTICIPATION IN THE WorLd TRADE ORgANIZATION
}

\author{
Steve Charnovitz*
}

The World Trade Organization (WTO) is frequently criticized for insufficient transparency and for a lack of participatory opportunities for private individuals and civic society. ${ }^{1}$ For example, consider the views of Lori Wallach, one of the most prominent opponents of the WTO. ${ }^{2}$ In a recently-published "comprehensive guide to the WTO" coauthored by Wallach and her colleague Patrick Woodall, a series of criticisms were leveled, including the following:

WTO business is conducted by committees and panels that meet behind closed doors in Geneva, Switzerland.

In sharp contrast to domestic courts and even other international agreements, at the WTO there is a startling lack of transparency, public disclosure or accountability.

$\cdots$

... [T] he WTO is intentionally designed to insulate against democratic pressure for change. ${ }^{3}$

Because Wallach is an outsider to the WTO, it would be fair to balance her views against what the insiders are saying. One insider and frequent WTO defender is James Bacchus, a former U.S. Congressman and an original member of the WTO Appellate Body who served on that tribunal longer than anyone else. 4 After departing from the Appellate Body in early 2004, Bacchus wrote an op-ed for the Washington Post in which he said:

We must open the doors of the WTO. We need to let in the light of public scrutiny-let the 6 billion people in the world who are served by the WTO see the organization as it really is.

\footnotetext{
* Associate Professor of Law, George Washington University Law School. Forthcoming Rutgers Law Review, 2005.

1. Philippe Legrain, Open World: The Truth About Globalisation 200-01 (2002).

2. Moisés Naim, Lori's War, FoREIGN POL'Y, Spring 2000, at 29 (an interview with Lori Wallach), available at http://www.foreignpolicy.com/Issue119PDfs/2855wallach.pdf (last visited Nov. 3, 2004).

3. Lori Wallach \& Patrick Woodall, Whose Trade Organization? A COMPREHENSIVE GUIDE TO THE WTO 15-16 (2004).

4. See generally JAMEs Bacchus, TRADE AND FrEedom (2004).
} 
... Those who oppose the WTO can portray it in the distorted way they do only because, by keeping the doors closed, the organization's members make it possible, and seemingly credible, for them to do so. ${ }^{5}$

In my opinion, Wallach and Bacchus stand as far apart as two people can be on the overall merits for humanity of the WTO and international trade. Yet both share the view that the WTO is deficient with respect to its openness.

I agree with such criticism and join others in this symposium to urge that the WTO promote greater public understanding and citizen participation. My specific contribution will be to point out the common thread between the norms espoused by the WTO for national transparency and the analogous norms now lacking within the WTO as an organization. Promoting transparency and participation in each of the two levels of governance-national and international-will be mutually reinforcing and serve to enhance governmental accountability.

This article proceeds in the following manner. Part I explores the development in international trade law of the norm for transparency and participation at the national level. Part II describes the WTO's practices regarding openness and public participation, and then criticizes the current limitations. In doing so, I discuss why the WTO's norms for national government should be applied to the international trading system and why administrative law principles are relevant to the WTO. Part III proposes several new steps for the WTO to take to promote transparency and participation. Part IV concludes.

\section{Development of the National TRAnsparency Norm in INTERNATIONAL TRADE LAW}

Although I am unaware of any historical study of the emergence of international norms on transparency and citizen participation, some key moments are apparent. One foundational development was Immanuel Kant's attention to "capacity for publicity" in his essay Perpetual Peace (1795). ${ }^{6}$ In Kant's view, the "transcendental formula of public right" (or public law) is that "[a]ll actions that affect

5. James Bacchus, Open Up the WTO, WASH. Post, Feb. 20, 2004, at A25 (emphasis original).

6. Immanuel Kant, To Perpetual Peace. A Philosophical Sketch, in PERPETUAL Peace ANd Other Essays on Politics, History, and Morals 107, 135 (Ted Humphrey trans., 1983); see Ruth Buchanan, Perpetual Peace or Perpetual Process: Global Civil Society and Cosmopolitan Legacy at the World Trade Organization, 16 LEIDEN J. INT'L L. 673, 692 (2003) (noting that Kant's emphasis on publicity prefigures the current transparency debate). 
the rights of other men are wrong if their maxim is not consistent with publicity." 7 An important intergovernmental action was the inclusion of Article 18 in the Treaty of Versailles providing that "[e]very treaty or international" agreement shall be registered by the Secretariat of the League of Nations and "shall as soon as possible be published by it[,]" and, furthermore, that "[n]o such treaty or international engagement shall be binding until so registered." 8 These developments may have provided intellectual context for the emergence of transparency as an issue of international trade law.

The foundation stone of international norms for transparency was the 1923 International Convention Relating to the Simplification of Customs Formalities ("Customs Convention").9 The Customs Convention established rules for transparency and review at the national level.10 All customs regulations were required to be promptly published "in such a manner as to enable persons concerned to become acquainted with them and to avoid the prejudice which might result from the application of customs formalities of which they are ignorant."11 Moreover, no customs regulations were to be enforced before being published unless "previous publication would be likely to injure the essential interests of the [regulating] country."12 With regard to import and export licenses, the Customs Convention dictated that the conditions to be fulfilled "should be brought immediately in the clearest and most definite form to the notice of the public."13 Following implementation of a regulation, the Convention directed states to use "the most appropriate measures by their national legislation and administration, both to prevent the arbitrary or unjust application of their laws[,] . . . and to ensure redress by administrative, judicial or arbitral procedure for those who may have been prejudiced by such abuses."14 If a dispute arose between the parties on these commitments, either party could refer the matter to the Permanent Court of International Justice. ${ }^{15}$ No referrals to the Permanent Court

7. Kant, supra note 6 , at 135.

8. Treaty of Peace Between the Allied and Associated Powers and Germany, June 28, 1919, The Treaties of Peace 1919-1923, Vol.1, art. 18 [hereinafter Treaty of Versailles]. Writing in 1919, the educator David Jayne Hill noted the significance of this provision. DAVID JaYne Hill, PRESENT PRoblems in Foreign Policy 34-35 (1919).

9. International Convention Relating to the Simplification of Customs Formalities, Nov. 3, 1923, 19 AM. J. INT'L L. SuPP. 146 (1925) [hereinafter Customs Convention]. The United States was not a party to this Convention.

10. See id.

11. Id. art. 4. Customs regulations were defined broadly to include "tariffs and [all] import and export prohibitions or restrictions." Id.

12. Id.

13. Id. art. 3(a).

14. Id. art. 7.

15. Id. art. 22, para. 3. This applied to the rule about enforcement before 
occurred. 16

This international customs law is remarkable in its modernity. The Customs Convention supervises the domestic policy process, and the designated beneficiaries are not only the parties to the Convention but also "persons concerned," 17 a class that could include domestic persons as well as aliens. Furthermore, the Convention's rules are backed up by dispute settlement. It is also interesting to note that the Protocol to the Convention contains what is now called a "savings clause"18 to defer to past or future international treaties relating to the preservation of the health of human beings, animals, or plants and to the protection of public morals or international security. ${ }^{19}$

The Convention itself lacks any provision about transparency and nongovernmental participation in the Convention's implementation. 20 No historical account of the Convention's implementation is readily available, and I do not know the extent of transparency attained. In general, the economic activities of the League of Nations did feature considerable transparency and some private participation. ${ }^{21}$

The Convention's history is clear in one interesting respect, namely, an unusually inclusive negotiating process. ${ }^{22}$ The depth of the Convention's commitment to transparency can be traced to the extensive participation by the International Chamber of Commerce

publication, but not to the rule about prompt publication. Id. art. 22, para. 3. For that rule, the parties had to agree on referring the dispute to an arbitral or judicial procedure. Id. art. 22, para. 1. In ratifying the Customs Convention, Roumania declared its understanding that Article 22 applies to questions of a general nature, with "private persons being only entitled to appeal to their own judicial authorities." Id., at 165 .

16. See the following website for a list of cases of the Permanent Court of International Justice for the years 1922-1940, http://www.worldcourts.com/pcij/eng/pcij-listofcases.htm (last visited Nov. 3, 2004).

17. Customs Convention, supra note 9, art. 4. para. 1.

18. See Laurence R. Helfer, Constitutional Analogies in the International Legal System, 37 LOY. L.A. L. REV. 193, 218 (2003) (discussing a savings clause).

19. Customs Convention, supra note 9 , at 166.

20. See Customs Convention, supra note 9.

21. See generally H.R.G. GREAVES, The LEAGUe COMMitTEES AND WORLD ORDER (1931).

22. The process was inclusive in the sense of listening to the views of the organized business community. GEORGE L. RIDGEWAY, MERCHANTS OF PEACE 204, 20708, 211-14, 216, 232 (1938).Labor unions, women's groups, and environmentalists were not present at the negotiating conference, but to my knowledge, they did not ask to be. International Conference on Customs and Other Similar Formalities, League of Nations, C.D.I.96(1) (1923). The feature that was unusual about the 1923 conference was that the International Chamber of Commerce participated extensively. RIDGEWAY, supra, at 225. As George Ridgeway explained, the conference negotiations utilized the common feature of national government in which interested groups are given an opportunity to assist in shaping law. See RIDGEWAY, supra, at 212-13. 
in the Convention's drafting process. ${ }^{23}$ As historian George L. Ridgeway pointed out, "[t]he influence of the International Chamber was particularly noteworthy in the formation of policy on the subjects of publicity, treatment of commercial travelers and samples, and redress." 24

The Customs Convention episode provides a good illustration of the symbiosis between transparency and participation at the national and international levels because nongovernmental participation in an international conference was an important factor in getting governments to establish better norms for transparency at the national level. The fact that this norm developed so early in the international trade regime, rather than in other regimes, may be because transnational private interactions are the very essence of international trade. 25

By contrast, other international regimes were able to operate for a long time without much attention to the domestic regulatory process. ${ }^{26}$ For example, the international labor regime developed contemporaneously with the trade regime and yet the organic act of 1919 creating the International Labour Organization (ILO) omits considerations of transparency or due process at the national level. ${ }^{27}$ Not until 1960 did the ILO get around to giving concerted attention to the need for norms at the national level to improve governmental decisionmaking. ${ }^{28}$ In that year, the ILO approved Recommendation 113 concerning consultation and co-operation between public authorities and employers' and workers' organisations at the industrial and national levels. ${ }^{29}$ Among its purposes, the Recommendation aims to ensure that governments seek the views of these organizations in "the preparation and implementation of laws and regulations affecting their interests." 30 Note that the ILO's initial lack of transparency norms for governments stood in sharp contrast to its pathbreaking norms for the participation of nonstate actors-in particular, employer and worker organizations-in all ILO

23. See id. at 209-16.

24. Id. at 213. The International Chamber of Commerce was consulted by a working party of the GATT Contracting Parties in the early 1950s. See International Convention to Facilitate the Importation of Commercial Samples and Advertising Material, GATT, BISD 1S/94, paras. 3, 27, 29, 30.

25. See ARIKA IRIYE, Global Community 12-13 (2002) (noting the connection between capitalism and the development of nongovernmental organizations).

26. See Sir ARThur SAlter, World Trade AND Its Future 2-3 (1936) (explaining that "normally it is not nations but individuals that trade with each other").

27. See Treaty of Versailles, supra note 8, Part XIII (organizing the ILO).

28. See R113 Consultation (Industrial and National Levels) Recommendation, International Labour Organization (June 20, 1960), available at http://www.ilo.org./ilolex/cgi-lex/convde.pl?R113 (last visited Nov. 3, 2004).

29. Id.

30. Id. para. 5(b)(i). 
activities. ${ }^{31}$

When the United Nations convened negotiations on international trade in 1946, the governments used the Customs Convention as a reference point for writing new rules on the customs process. ${ }^{32}$ One might have expected the governments to build on and strengthen the disciplines in that Convention. Yet as John $\mathrm{H}$. Jackson has pointed out, what happened instead is that some of the provisions of the 1923 Convention were watered down to the point where the Charter of the International Trade Organization ("ITO") 33 and the General Agreement on Tariffs and Trade ("GATT") "represented a backward step." ${ }_{44}$

In regard to transparency, the major difference between the Customs Simplification Convention and GATT Article X (Publication and Administration of Trade Regulations), in my view, is that Article X's disciplines ${ }^{35}$ apply only to measures "of general application," 36

31. Treaty of Versailles, supra note 8, Part XIII; see generally ERNST B. HAAS,

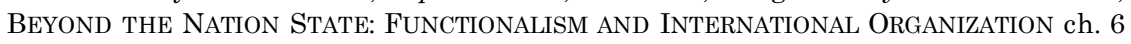
(1964) (discussing the organizational ideology of the ILO from 1919-1948).

32. JOHN H. JACKSON, WORLD TRADE AND THE LAW OF GATT 441 (1969).

33. Id.; see also RICHARD N. GARDNER, STERLING-DOLLAR DIPLOMACY 369-78 (1956) (discussing the end of the ITO and why it did not enter into force).

34. JACKSON, supra note 32, at 441; see General Agreement on Tariffs and Trade, Oct. 30, 1947, 61 Stat. A-11 [hereinafter GATT]. The GATT, as amended, is available at the WTO website, http://www.wto.org/english/docs_e/legal_e/legal_e.htm (last visited Nov. 3, 2004).

35. GATT Article $\mathrm{X}: 1$ states in part:

Laws, regulations, judicial decisions and administrative rulings of general application, made effective by any contracting party, pertaining to the classification or the valuation of products for customs purposes, or to rates of duty, taxes or other charges, or to requirements, restrictions or prohibitions on imports or exports or on the transfer of payments therefor, or affecting their sale,

distribution, transportation, insurance, warehousing inspection, exhibition, processing, mixing or other use, shall be published promptly in such a manner as to enable governments and traders to become acquainted with them.

GATT Article X:2 states in part:

No measure of general application taken by any contracting party effecting an advance in a rate of duty or other charge on imports under an established and uniform practice, or imposing a new or more burdensome requirement, restriction or prohibition on imports, or on the transfer of payments therefor, shall be enforced before such measure has been officially published.

GATT, supra note 34 , arts. X, paras. 1, 2.

36. GATT, supra note 34 , art. X, para. 2. The WTO Secretariat has published a useful note on the negotiating history of Article X in the 1946-48 period. See Article X of the GATT 1994 - Scope and Application, Note by the Secretariat, G/C/W/374, at 1-4 (May 14, 2002), http://www.wto.org/english/tratop_e/tradfa_e/tradfa_overview2002_e.htm (last visited Nov. 3, 2004). 
while the corresponding provisions in the Convention do not contain that limitation. ${ }^{37}$ In regard to the review of administrative action, the disciplines in the Convention and the GATT are similar except on one important point in which the GATT goes further. 38 The GATT requires that the review of administrative action regarding customs matters be done by tribunals or procedures that are "independent" of the agency that took the contested administrative action. ${ }^{39}$ In contrast, the Convention's provision for "redress" lacked an independence requirement. 40

From 1948 to 1995, only one case occurred in which a government's trade measure was challenged pursuant to GATT Article X and found to be a violation. 41 That was the 1989 decision in European Economic Community - Restrictions on Imports of Apples, a complaint by the United States.42 One charge in that dispute was that the European Economic Community ("EEC") had imposed a quota on apples effective February 14, 1988 yet did not publish the regulation until April 20, 1988.43 While noting that such publication met Article X:1's requirement that measures "be published promptly," the panel, nevertheless, held that the EEC's quota violated Article X:1 because (as the panel saw it) the provision prohibits "back-dated quotas." 44 The panel's reasoning is a bit hard to understand, however, because its decision reveals no arguments by the complaining government for the Article X violation. ${ }^{45}$ Litigation has occurred a bit more frequently in the WTO and the tendency of adjudicators has largely been deferential to national law.46 For

37. Compare GATT, supra note 34 , art. X, paras. 1, 2 (requiring publication of "[l]aws, regulations, judicial decisions and administrative rulings of general application"), with Customs Convention, supra note 9, art. 4 (requiring publication of "all regulations relating to customs and similar formalities").

38. Compare GATT, supra note 34, art. X, para. 3(b) with Customs Convention, supra note 9 , art. 7 .

39. GATT, supra note 34, art. X, para. 3(b).

40. Customs Convention, supra note 9, art. 7.

41. WTO, ANAlytical IndeX: Guide to GATT LAW AND PRACTiCE 295-98 (1995).

42. European Economic Community - Restrictions on Imports of Apples Complaint By the United States, Report of the Panel, BISD 36S/135 (adopted June 22, 1989), http://www.wto.org/english/tratop_e/dispu_e/gt47ds_e.htm (last visited Nov. 3, 2004).

43. Id. para. 5.22.

44. Id. paras. $5.21,5.23$.

45. See id. para. 5.1 (indicating no specific arguments by the U.S. government for the violation of Article X).

46. A narrow/strict interpretation has also occurred with regard to GATT Article $\mathrm{X}: 3(\mathrm{a})$ which requires governments to administer "laws, regulations, decisions, and rulings" in a "uniform, impartial, and reasonable manner all its laws, regulation." GATT, supra note 34, art. X, para. 3(a); see European Communities - Regime for the Importation, Sale and Distribution of Bananas, Report of the Appellate Body, WT/DS27/AB/R, paras. 200-01 (adopted Sept. 9, 1997), 
example, in European Communities - Measures Affecting the Importation of Certain Poultry Products, the Appellate Body held that GATT Article X:1 applies only to rules of general application, not to specific rulings for individual shipments. ${ }^{47}$

The only GATT Article X transparency violation found by a WTO tribunal occurred in United States - Restrictions on Imports of Cotton and Man-made Fibre Underwear, where the panel saw a violation of Article X:2 because the U.S. safeguard period was retroactive to imports occurring before the date of publication of the restraint. 48 The plaintiff government Costa Rica appealed some matters in Cotton Underwear, which gave the Appellate Body an opportunity in 1997 to expound GATT Article X. In its decision, the Appellate Body stated:

Article X:2, General Agreement, may be seen to embody a principle of fundamental importance - that of promoting full disclosure of governmental acts affecting Members and private persons and enterprises, whether of domestic or foreign nationality. The relevant policy principle is widely known as the principle of transparency and has obviously [sic] due process dimensions. The essential implication is that Members and other persons affected, or likely to be affected, by governmental measures imposing restraints, requirements and other burdens, should have a reasonable opportunity to acquire authentic information about such measures and accordingly to protect and adjust their activities or alternatively to seek modification of such measures. ${ }^{49}$

This is a significant interpretation because very few of the disciplines in GATT are generally thought to encompass persons and enterprises of domestic nationality vis-à-vis their own government. 50 Here the Appellate Body recognizes the fundamental nature of the transparency principle in GATT Article X:2 and its importance to private persons and enterprises on both sides of a transborder

http://www.wto.org/english/tratop_e/dispu_e/distab_e.htm (last visited Nov. 3, 2004) (reversing the panel and holding that the discipline in Article X:3(a) applies only to the administration of laws, regulations, etc., not to the laws and regulations themselves). In a subsequent case, the Appellate Body explained that complaints about the "substantive content" of national trade rules would not come within the scope of Article X. European Communities - Measures Affecting the Importation of Certain Poultry Products, Report of Appellate Body, WT/DS69/AB/R, para. 115 (adopted July 13, 1998), http://www.wto.org/english/tratop_e/dispu_e/69abre.pdf (last visited Nov. 3, 2004) [hereinafter EC Poultry Appellate Body Report].

47. EC Poultry Appellate Body Report, supra note 46, paras. 113-15.

48. United States - Restrictions on Imports of Cotton and Man-made Fibre Underwear, Report of the Appellate Body, WT/DS24/AB/R, at 21 (adopted Feb. 25, 1997), http://www.wto.org/english/tratop_e/dispu_e/distab_e.htm (last visited Nov. 3, 2004) [hereinafter U.S. Cotton Underwear Appellate Body Report].

49. Id.

50. JACKSON, supra note 32, at 187. 
transaction.51 Moreover, the Appellate Body sees a "due process" dimension to transparency, and seems to suggest that Article X has implications not only for WTO Members but also for "other persons" who should have a reasonable opportunity to acquire the information about a customs measure that will enable them either to adjust their activities or to go to a government "to seek modification of such measures." ${ }_{2} 2$ This is the first caselaw of the WTO to explicitly make the connection between information transparency for the public and the ability of the affected individual to act on the information by participating in a government's administrative review process. ${ }^{53}$

The Appellate Body returned to GATT Article X in the United States - Import Prohibition of Certain Shrimp and Shrimp Products case. ${ }^{54}$ At issue was whether the U.S. import ban on shrimp could be justified under the General Exceptions in GATT Article XX.55 Sua sponte, the Appellate Body stated that GATT Article X:3 could aid in the interpretation of Article XX because Article X:3 "establishes certain minimum standards for transparency and procedural fairness in the administration of trade regulations . . . "56 The issue of procedural fairness had arisen because the Appellate Body had found that the U.S. government denied "basic fairness and due process" to foreign governments applying for certification under the U.S. shrimp-turtle regulation. 57

The transparency and review principles in GATT Article X served as an inspiration to governments in the drafting of analogous provisions in many of the new Uruguay Round agreements for goods, services, and intellectual property. ${ }^{58}$ For example, the provisions in GATT Articles X:1 and X:2 on publication are reflected in Article 7 (Transparency) of the Agreement on the Application of Sanitary and Phytosanitary Measures, ${ }^{59}$ in Article III (Transparency) of the

51. U.S. Cotton Underwear Appellate Body Report, supra note 48, at 21.

52. $I d$.

53. See id.

54. Report of the Appellate Body, WT/DS58/AB/R (adopted Oct. 12, 1998), http://www.wto.org/english/tratop_e/dispu_e/58abr.pdf (last visited Nov. 3, 2004) [hereinafter U.S. Shrimp Appellate Body Report]; see also Armin von Bogdandy, Legitimacy of International Economic Governance: Interpretive Approaches to WTO Law and the Prospects of its Proceduralization, in INTERNATIONAL ECONOMIC GOvernance AND Non-Economic CONCERns 103, 131 (Stefan Griller ed., 2003) (discussing the Appellate Body's rulings on GATT Article X).

55. U.S. Shrimp Appellate Body Report, supra note 54, paras. 1, 98.

56. Id. para. 183.

57. Id. para. 181.

58. See Marrakesh Agreement Establishing the World Trade Organization, Apr. 15, 1994, $33 \quad$ I.L.M. $1144 \quad$ (1994), available at http://www.wto.org/english/docs_e/legal_e/04-wto.pdf (last visited Nov. 3, 2004) [hereinafter WTO Agreement].

59. Agreement on the Application of Sanitary and Phytosanitary Measures, WTO 
General Agreement on Trade in Services (GATS), 60 in Article 12 of the Customs Valuation Agreement,61 and in Article 63 (Transparency) of the Agreement on Trade-Related Aspects of Intellectual Property Rights ("TRIPS").62 The provisions in GATT Article X:3(b) on independent review are reflected, for example, in Article 13 (Judicial Review) of the Antidumping Agreement, 63 in GATS Article VI:2(a), 64 and in TRIPS Article 41.4.65

In one important area, however, the governments drafting the Marrakesh Agreement Establishing the World Trade Organization ("WTO Agreement")66 went beyond the transparency principles in GATT Article $\mathrm{X}$ to develop a new participation principle for the WTO.67 Under this principle, private economic actors should have a right to participate in the making of designated types of trade policy at the national level. The need for enhancing such participation had been recommended by the "Leutwiler Group" report of 1985, and that recommendation may have influenced the drafting of the WTO Agreement over the next several years. 68

Agreement, Annex 1A, art. 7 (1994), http://www.wto.org/english/docs_e/legal_e/15sps.pdf (last visited Nov. 3, 2004) [hereinafter SPS Agreement].

60. General Agreement on Trade in Services, WTO Agreement, Annex 1B, art. III (1994), http://www.wto.org/english/docs_e/legal_e/26-gats.pdf (last visited Nov. 3, 2004) [hereinafter GATS].

61. Agreement on Implementation of Article VII of the General Agreement on Tariffs and Trade 1994, WTO Agreement, Annex 1A, art. 12, http://www.wto.org/english/docs_e/legal_e/20-val_01_e.htm (last visited Nov. 3, 2004) (known as the "Customs Valuation Agreement").

62. Agreement on Trade-Related Aspects of Intellectual Property Rights, WTO Agreement, Annex 1C, art. 63, 33 I.L.M. 1197 (1994), available at http://www.wto.org/english/docs_e/legal_e/27-trips.pdf (last visited Nov. 3, 2004) [hereinafter TRIPS Agreement].

63. Agreement on Implementation of Article VI of the General Agreement on Tariffs and Trade 1994, WTO Agreement, Annex 1A, art. 13 (1994), http://www.wto.org/english/docs_e/legal_e/19-adp.pdf (last visited Nov. 3, 2004) [hereinafter Antidumping Agreement].

64. GATS, supra note 60, art. VI, para. 2(a).

65. TRIPS Agreement, supra note 62, art. 41, para. 4. See Ernst-Ulrich Petersmann, International Trade Law and the GATT/WTO Dispute Settlement System 1948-1996: An Introduction, in INTERNATIONAL TRADE LAW AND THE GATT/WTO Dispute SETTLEMENT System 3, $72-74$ (Ernst-Ulrich Petersmann ed., 1997), for a discussion on judicial review in WTO law. The issue of judicial review at the national level is separable from transparency and participation, and is too large an issue to be covered here.

66. See WTO Agreement, supra note 58.

67. Robert Wolfe, Regulatory Transparency, Developing Countries and the WTO, 2 WORLD TRADE REV. 157, 161 (2003).

68. See GATT, Trade Policies for a Better Future: Proposals for ACtion 36 (1985) (suggesting that all countries develop organizations in which interested parties and consumers can express their views on trade policy actions before decisions are made). This report was written by a seven-man eminent persons group chaired by Fritz Leutwiler, a noted Swiss and international banker. 
Provisions to provide private participatory rights and opportunities at the national level are present in many of WTO subagreements. ${ }^{69}$ For example, the Agreement on Safeguards states that a government's investigation shall provide for public hearings (or other appropriate means) in which importers, exporters, and other interested parties can present evidence and their views. ${ }^{70}$ The GATS states that where appropriate, WTO Members "shall work in cooperation with relevant intergovernmental and nongovernmental organisations towards the establishment and adoption of common international standards and criteria for recognition" for the practice of relevant services trades and professions.71 The Agreement on Technical Barriers to Trade (TBT) provides that before adopting a standard, a national standardizing body is to allow a period of at least 60 days for interested parties to submit comments on the draft standard (unless urgent problems arise). ${ }^{72}$ Furthermore, the standardizing body is required to "take into account" such comments.73 The Antidumping Agreement has an Article on "Public Notice and Explanation of Determinations" and also requires that the antidumping adjudication provide opportunities for interested parties to provide evidence and for consumer organizations to provide information. ${ }^{74}$ WTO member governments have gone even further in providing for private participatory rights in the context of accession agreements whereby governments join the WTO.75 The most

69. None of these WTO provisions provide for participation in the national legislative process.

70. Agreement on Safeguards, WTO Agreement, Annex 1A, art. 3.1 (1994), http://www.wto.org/english/docs_e/legal_e/25-safeg.pdf (last visited Nov. 3, 2004).

71. GATS, supra note 60, art. VII, para. 5.

72. Agreement on Technical Barriers to Trade [hereinafter TBT Agreement], WTO Agreement, Annex 1A, Annex 3, Code of Good Practice for the Preparation, Adoption, and Application of Standards, para. L (1994), http://www.wto.org/english/docs_e/legal_e/17-tbt.pdf (last visited Nov. 3, 2004) (requiring interested parties to be within the territory of a WTO member country) [hereinafter Code of Good Practice]. The WTO has published a booklet on the TBT's transparency requirements. See WTO Secretariat, Transparency Provisions of the TBT Agreement, April 2002, http://www.wto.org/english/tratop_e/tbt_e/booklet_transparency_e.doc (last visited Nov. 3, 2004).

73. Code of Good Practice, supra note 72, para. N. These obligations inure to bodies that have accepted the Code and WTO member governments are responsible for assuring that central government standardizing bodies accept the Code. TBT Agreement, supra note 72, art. 4.

74. Antidumping Agreement, supra note 63, arts. 6.1.2, 6.12, 12.

75. See, e.g., Report of the Working Party on the Accession of Cambodia, WT/ACC/KHM/21, para. 216 (Aug. http://www.wto.org/english/thewto_e/acc_e/completeacc_e.htm (last visited Nov. 3, 2004). 
expansive demands came in the negotiations with China.76 As Julia Ya Qin has pointed out, China agreed to provide an opportunity for public comment on all new draft laws and regulations affecting trade.77 Qin notes that this "mandatory public comment period clearly exceeds the requirements of existing WTO rules."78

In summary, with regard to its oversight of national trade and trade-related regulation, WTO law requires governments to maintain a large degree of transparency and some degree of participation for the benefit of traders and other interested persons. 79 This law demonstrates an acknowledgement by governments that transparency and participation are important ingredients in good governance at the national level.

\section{Development of Transparency Norms Within the WTO}

Unfortunately, WTO member governments have adopted a different and inconsistent position with regard to norms for WTO transparency and to the participation of nonstate actors in the policy and rulemaking activities of the WTO.80 Although the text of the WTO Agreement does not require that WTO negotiations be kept confidential and does not forbid participatory opportunities for the public, the WTO has often insisted on secrecy and resisted participation by social and economic actors. 81 That said, it needs to be noted that the zone of secrecy and insularity has continued to narrow since the WTO was born in $1995 .{ }^{82}$ Still, a great deal of room for improvement exists.

Let me briefly summarize the current practices of the WTO regarding transparency and participation. The WTO website has many download options and features a huge collection of documents

76. See Julia Ya Qin, "WTO-Plus" Obligations and Their Implications for the World Trade Organization Legal System, 37 J. WORLD TRADE 483, 491-93 (2003) (noting the WTO negotiations with China).

77. Id. at 493 .

78. $I d$.

79. Cf. Peter M. Gerhart, The Two Constitutional Visions of the World Trade Organization, 24 U. PA. J. INT'L ECON. L. 1, 61 (2003) ("It is no exaggeration to say that the WTO treaties form a kind of Administrative Procedure Act for foreigners who might be adversely affected by government action.") (footnote omitted).

80. See Frank Loy, Public Participation in the World Trade Organization, in THE ROLE OF THE WORLD TRADE ORGANIZATION IN GLOBAL GOVERNANCE 113, 119-21 (Gary P. Sampson ed., 2001).

81. See Julio A. Lacarte, Transparency, Public Debate and Participation by NGOs in the WTO: A WTO Perspective, 7 J. INT'L ECON. L. 683, 683-84 (2004).

82. See, e.g., Procedures for the Circulation and Derestriction of WTO Documents, WT/L/452 (May 14, 2002), http://www.wto.org/english/forums_e/ngo_e/bernie_derestrictiontext_e.htm (last visited Nov. 3, 2004). 
available without charge. ${ }^{83}$ For WTO legislative activities, the main exclusions are draft negotiating texts and some analyses prepared by the Secretariat. ${ }^{84}$ For WTO judicial activities, the main exclusions are the government briefs to the panels and Appellate Body, interlocutory procedural rulings, and the panel's interim report. 85 Most documents are posted in a timely manner except for minutes of various WTO meetings which tend to lag a few months. Other than plenary sessions of WTO Ministerial Conferences, all official WTO meetings are closed to the private sector and nongovernmental organizations ("NGOs"). 86 Over the past decade, however, the WTO Secretariat has organized a number of seminars, symposia, and workshops in which accredited NGOs and business representatives participate. 87

With regard to dispute settlement, all oral hearings of WTO panels and the Appellate Body are closed to the public.88 On many occasions in recent years, NGOs and private individuals have submitted unsolicited amicus curiae briefs to panels and the Appellate Body. 89 Subsequent to the Appellate Body's landmark decision in 1998 in favor of the admissibility of amicus curiae

83. See http://www.wto.org. See also HetTy Kovach ET AL., ONE WORLD TRUST, THE Global AcCountability RePort: Power Without ACCOUntability? 15 (2003), available at http://www.oneworldtrust.org/htmlGAP/report/report.htm (last visited Nov. 3, 2004), which rated the WTO second among the reviewed international organizations for access to online information.

84. The "JOBS" document series, covering negotiations, are not released by the WTO. See http://docsonline.wto.org/gen_search.asp? searchmode=advanced (last visited Nov. 3, 2004) (By selecting "Advanced Search" and entering "Jobs" in "Collection" field, one will reach an error page that indicates that this document "is not yet available to the public.").

85. Understanding on Rules and Procedures Governing the Settlement of Disputes, WTO Agreement, Annex 2, 33 I.L.M. 1226, arts. 4.6, 13.1, 14.1, 17.10, 18.2 (1994), http://www.wto.org/english/docs_e/legal_e/28-dsu.pdf (last visited Nov. 3, 2004) [hereinafter DSU]. A panel's interim report is not made public, but the final report discusses any changes made to the interim report following review and comment by the parties. In practice, the decision reached in an interim report is often leaked to the press. See, e.g., Gambling Ban Struck Down, WASH. Post, Mar. 25, 2004, at E2 (reporting on interim ruling in U.S. online gambling case).

86. DAVID J. BEDERMAN, INTERNATIONAL LAW FRAMEWORKS 145 (2001) ("The virtual entirety of WTO proceedings are closed to public view.").

87. See, e.g., World Trade OrG., WORkshop ON Domestic Regulation PRoGramme (Mar. 29-30, 2004), http://www.wto.org/english/tratop_e/serv_e/workshop_march04_e/workshop_program me_march04_e.htm (last visited Nov. 3, 2004) (detailing an agenda of a workshop held by the WTO Secretariat on domestic regulation that included presentation by persons from International Bar Associations, the International Union of Architects, the International Council of Nurses, and the European Express Association).

88. WALLACH \& WOODALL, supra note 3 , at 245.

89. David Palmeter \& Petros C. Mavroidis, Dispute Settlement in the World Trade Organization, Practice and Procedure 35-36 (2nd ed. 2004). 
briefs, ${ }^{90}$ a common practice is that the Appellate Body will consider accepting an amicus brief, yet will not take it into account in deciding the case. ${ }^{91}$ The panel practice is more variable. A trend that may be developing is that the panel makes a preliminary ruling that it will consider arguments in an amicus curiae brief only to the extent that the argument is voiced by one of the governmental parties. ${ }^{92}$

The WTO Agreement, Article V:2, provides authority to the WTO General Council to "make appropriate arrangements for consultation and cooperation with non-governmental organizations concerned with matters related to those of the WTO." 93 Article V:2 was based on a similar institutional provision in the ITO Charter, ${ }^{94}$ which was modeled on one in the U.N. Charter. ${ }^{95}$ The WTO General Council implemented Article V:2 in 1996 by enacting Guidelines for Arrangements with NGOs. ${ }^{96}$

These Guidelines delineate a narrow role for NGOs based on the following rationale:

As a result of extensive discussions, there is currently a broadly held view that it would not be possible for NGOs to be directly involved in the work of the WTO or its meetings.

90. See U.S. Shrimp Appellate Body Report, supra note 54, paras. 104-10 (explaining the admissibility of amicus curiae briefs). The trend to accept NGO participation in intergovernmental litigation was first reported on by Dinah Shelton. See Dinah Shelton, The Participation of Nongovernmental Organizations in International Judicial Proceedings, 88 AM. J. INT'L L. 611, 616 (1994) (noting the positive development in the acceptance of amicus participation by NGOs in international cases).

91. See, e.g., United States - Imposition of Countervailing Duties on Certain HotRolled Lead and Bismuth Carbon Steel Products Originating in the United Kingdom, Report of the Appellate Body, WT/DS138/AB/R, para. 42 (adopted May 10, 2000), http://www.wto.org/english/tratop_e/dispu_e/2340d.pdf (last visited Nov. 3, 2004) (where the Appellate Body found it unnecessary to take the amicus curiae briefs into account, but held they had the authority to do so).

92. See United States - Final Countervailing Duty Determination with Respect to Certain Softwood Lumber from Canada, Report of the Panel, WT/DS257/R, para. 7.1 n. 75 (adopted Feb. 17, 2004), http://www.wto.org/english/tratop_e/dispu_e/257r_a_e.doc (last visited Nov. 3, 2004) [hereinafter Softwood Lumber Final Determination].

93. WTO Agreement, supra note 58, art. V, para. 2.

94. See Final Act of the United Nations Conference on Trade and Employment: Havana Charter for an International Trade Organization, Mar. 24, 1948, art. 87, para. 2, http://www.wto.org/english/docs_e/legal_e/havana_e.pdf (last visited Nov. 3, 2004) [hereinafter Havana Charter for an ITO].

95. U.N. CHARTER art. 71. As Susan Aaronson points out, "[a]lthough the architects of the ITO provided for a role for civil society, the GATT bureaucracy turned insular." Susan Ariel Aaronson, TAKing Trade to the StreEts: The Lost History of PUblic EFFoRTs to SHAPE GLOBALIZATION 54 (2001).

96. Guidelines for Arrangements on Relations with Non-Governmental Organizations, WT/L/162 (July $\quad$ 23, http://www.wto.org/english/forums_e/ngo_e/guide_e.htm (last visited Nov. 3, 2004) [hereinafter NGO Guidelines]. 
Closer consultation and cooperation with NGOs can also be met constructively through appropriate processes at the national level where lies primary responsibility for taking into account the different elements of public interest which are brought to bear on trade policy-making. ${ }^{97}$

The General Council did not seek to explain why governments held that view and why they thought that the WTO was different from other international organizations where it is possible for NGOs to be directly involved in ongoing work and to observe it firsthand. Furthermore, the Council did not explain why the national level has the primary responsibility to take into account different elements of the public interest on trade policymaking, and if so, what remains as the raison d'être of the WTO. The narrowness of the assumption undergirding the Guidelines shows that a great deal more transparency and inclusion could be achieved by the WTO without having to renegotiate the treaty.

What would be the rationale for such a reform? In my view, the different positions espoused by the WTO for states and for itself cannot be reconciled. Prescribing outwardly to the national level, the WTO pushes the boundaries of international law regarding the need for transparency and participation. Yet in self-government, the WTO resists adopting features of transparency and participation practiced in other international organizations.

That inconsistent stance is troubling. Simply put, the WTO should practice what it preaches. The "principle of fundamental importance" articulated by the Appellate Body in the Cotton Underwear case that WTO members "and other persons affected, or likely to be affected, by governmental measures ... should have a reasonable opportunity to acquire authentic information about such measures and accordingly to protect and adjust their activities or alternatively to seek modification of such measures" applies just as much to WTO measures as it does to national measures. 98

The position expressed in the Guidelines that NGOs should limit their participation to the national level is based on an orthodox view of international relations. The key assumption is that states are the only relevant actors in international relations and that states should speak with a unitary voice to each other. Within each state, it is entirely appropriate for the ruling government to solicit the views of domestic (or foreign) actors in the setting of trade policy.99 At the WTO, however, it is thought that the flow of ideas

97. Id. para. VI.

98. U.S. Cotton Underwear Appellate Body Report, supra note 48, at 21.

99. See Brian Hocking, Changing the Terms of Trade Policy Making: From the "Club" to the "Multistakeholder Model," 3 WORLD TRADE REV. 3 (2004) (discussing new developments in modes of participation at the national level). 
has to be channeled through member governments.

In my view, this position may be coherent in the abstract, but is inappropriate for life on a planet that shares a common environment and increasingly, a common economy and social community. By denying the opportunity for NGOs to observe and participate more in WTO activities, the WTO is undermining its opportunity to promote greater transparency, participation, and accountability at the national level. Certainly, the WTO sets a bad example. Even worse, the WTO's reputation for secretiveness and single-mindedness may make it harder to maintain public support for the world trading system.

For instance, in the United States, the 2002 law providing trade promotion authority passed the U.S. House of Representatives by three votes. ${ }^{100}$ That law sets U.S. objectives for WTO negotiations, and one objective, on "Transparency," calls for "public access for appropriate meetings, proceedings, and submissions" to and at the WTO.101 If this U.S. objective remains unrequited, then future Congressional votes regarding the WTO may not go as positively.

\section{A. Administrative Law at the $W_{T O}{ }^{102}$}

The politics aside, some conceptual issues call for attention. A core question is whether the WTO's requirements for publication, notice and comment, and judicial review at the national level are relevant principles to be applied reflexively to the intergovernmental WTO. Similar requirements at the national level are generally understood as a means to promote the accountability of and democratic control over administrative agencies operating with delegated authority from lawmakers. But is the WTO an international administrative agency to which such principles might logically be applied?

The WTO does not lend itself to easy typologies, but in my view, it can be seen as an international administrative agency. The member governments that established the WTO endowed it with "such legal capacity as may be necessary for the exercise of its

100. Rossella Brevetti et al., Trade Policy: Senate Set to Clear Trade Package After House Approves Bill by 3 Votes, INT'L TrADE REP. (BNA), Aug. 1, 2002, at 1334.

101. Trade Act of 2002, Pub. L. No. 107-210, § 2102(b)(5)(B), 116 Stat. 933, 996 (2002).

102. In this article, I do not explore the connection between the changing vision of the WTO's responsibilities and the broader issue of the responsibility of international organizations for following general international law. For an introduction to the issue of the responsibility of international organizations, see JAN KLABBERS, AN INTRODUCTION TO INTERNATIONAL INSTITUTIONAL LAW ch. 14 (2002). In addition, I do not discuss the most common concern of international administrative law regarding the law governing how an international organization treats its employees. See C. Wilfred JENKs, ThE Proper LAW OF International ORGANisATIONs 27-33 (1962); C.F. AMERASINGHe, PRINCIPLES OF the InstitutionaL LAW OF INTERNATIONAL ORGANIZATIONS ch. 11 (1996). 
functions," and also provided that WTO officials would have the privileges and immunities necessary for the "independent exercise" of their functions. ${ }^{103}$ The main functions of the WTO are to "facilitate the implementation, administration and operation, and further the objectives" of the WTO Agreement, and to "provide the forum for [trade]negotiations." 104 During the course of trade negotiations, the WTO Members may agree to make amendments to WTO law and to the schedules containing national commitments on trade in goods and services. 105

Some might resist the notion of the WTO as an administrative agency on the grounds that it is a legislative body, but that claim is weak. Because trade negotiations are so central to the WTO's mission, the WTO could be characterized as an international legislature. As a legislature, however, the WTO has an unusual decision rule. In general, any action by the WTO requires consensus. ${ }^{106}$ Moreover, even after an amendment to the WTO is approved, that amendment has to be accepted by a member government before becoming binding on that government.107 Thus, member governments do not transfer or cede lawmaking power to the WTO.

On the other hand, some might embrace the notion of the WTO as an administrative agency on the false grounds that governments delegate decisionmaking authority to it, yet such a claim is mistaken. ${ }^{108} \mathrm{~A}$ state cannot delegate authority that it does not have and none of the international functions of the WTO are accomplishable by a solitary state. What has happened instead is that governments have established and joined the WTO, agreed to abstain from practices that violate WTO law, and assigned the WTO certain functions for promoting trade cooperation. 109 The governments have also assigned adjudicatory and compliance functions to the

103. See WTO Agreement, supra note 58, art. VIII, paras. 1, 3; Michael N. Barnett \& Martha Finnemore, The Politics, Power, and Pathologies of International Organizations, 53 INT'L ORG. 699 (1999) (viewing international organizations as purposive actors).

104. See WTO Agreement, supra note 58, art. III, paras. 1, 2.

105. See, e.g., WTO Agreement, supra note 58, art. X; GATT, supra note 34, art. XXVIII bis; GATS, supra note 60, art. XIX.

106. See WTO Agreement, supra note 58, art. IX, para. 1 (calling for decisionmaking by consensus but also providing for majoritarian decisionmaking).

107. WTO Agreement, supra note 58, art. X. The only exception is amendments to certain provisions in GATS which may become binding on all Members "upon acceptance by two-thirds of the Members." Id. art. X. para. 5. Waivers of WTO law can be approved by three-fourths of the Members. Id. art. IX, para. 3.

108. For an analysis of international delegations from a U.S. perspective, see Edward T. Swaine, The Constitutionality of International Delegations, 104 CoLUM. L. REV. 1492 (2004).

109. WTO Agreement, supra note 58, arts. I, III, XI, para. 1, XII, para. 1, XVI, para. 4. 
WTO Dispute Settlement Body and its panels and Appellate Body.110 Although some might argue that governments have delegated judicial (or quasi-judicial) authority to the Appellate Body, that claim is faulty because there was no pre-existing national jurisdiction to adjudicate a foreign government's compliance with WTO law.111 Instead, the governments have created a judicial function at the WTO.

The feature of the WTO that most renders it an administrative agency is that the principals-that is, the Members-have given the WTO competence as their joint agent to carry out certain discrete international functions. Because the Members are incorporeal, they must act through various agents including WTO "officials" and "the representatives of the Members."112 Within each government, the representative of that Member tends to be an Executive official.113 Thus, from the perspective of a national legislature, the WTO resembles an administrative agency in the sense that it makes decisions that affect a domestic polity and yet extend beyond the direct legislative control of national elected officials. 114

It is that similarity to the domestic agency that forms the basis for the application of administrative law principles to the WTO itself. Just as a legislature would impose administrative law on a domestic agency to make it more fair, transparent, and accountable, that legislature could conceptualize a similar role for the application of administrative law principles to the WTO.115 In doing so, the legislature (or the electorate) might have two targets in mind: one will be the WTO and its decisionmaking. The other will be the government's own representatives to the WTO for which WTO secrecy may present a barrier to effective parliamentary (and public)

110. Id. art. IV, para. 3; DSU, supra note 85.

111. With respect to a foreign government, there would be a problem of sovereign immunity of governmental acts. RESTATEMENT (THIRD) OF FOREIGN RELATIONS LAW § 451 (1987). I read the WTO DSU as implicitly preserving for Member A the judicial power to determine whether A is in compliance with the WTO treaty. See DSU, supra note 85, arts. 23.1, 23.2(a). Nevertheless, I am not aware of any WTO Member where a national court is routinely reviewing whether that Member government (or a subnational government) stands in compliance with WTO law.

112 See WTO Agreement, supra note 58, art. VIII, para. 3.

113. In some countries, the representative to the WTO Ministerial Council is an elected parliamentarian—for example, Mark Vaile, the Australian Trade Minister.

114. See Oxfam, Rigged Rules and Double Standards: Trade, Globalization, AND THE Fight AGAINST POVERTY 255 (2002) ("The problem is that most governments can enter into agreements at the WTO without sufficient reference to public opinion or parliamentary scrutiny, even though those agreements often involve important constraints on national policy.").

115. See Daniel Bodansky, The Legitimacy of International Governance: A Coming Challenge for International Environmental Law?, 93 AM. J. INT'L L. 596, 619 (1999) (suggesting that administrative procedure requirements at the international level "have the potential to serve the same legitimating functions as they do domestically"). 
oversight. 116

Since each WTO Member's interaction with the WTO is carried out through bureaucrats, diplomats, and occasionally ministers, there is a continuing need to achieve accountability for the authority that diplomatic and bureaucratic agents exercise at the WTO.117 The most obvious context for such accountability is the chain from the agent in Geneva to elected officials at home and then outward to the national citizenry. Yet in a world economy and in an organization like the WTO that operates by consensus, more inclusive and complex chains of accountability may be desirable.118

Legal analysts have not yet developed adequate frameworks for understanding the accountability of intergovernmental decisionmaking beyond governments to extragovernmental stakeholders wherever they are situated.119 Although the norms intrinsic to national-level democracy may not be directly applicable to

116. See Paul B. Stephan, International Governance and American Democracy, 1 CHI. J. INT'L L. 237, 250 (2000) (stating that the secrecy of international organizations makes it hard to monitor government action). This problem would be reduced if governments maintained the same transparency with respect to actions abroad as they do with respect to actions in the homeland. Allott has suggested that accountability expectations accompany a government as it operates internationally. PHILIP ALLOTT, The Health of Nations: Society And LaW Beyond the State 378 (2002) ("When a government exercises public-realm power externally, in relation to other governments, including in the forming of intergovernmental societies, it carries with it the constitutional conditions on the exercise of that power.").

117. Howse points out several ways in which WTO processes tend to loosen the accountability of agents in Geneva to the principals back home. For example, the bunching of decisions into a large package makes it harder for national legislatures to reject what negotiators have achieved. Robert Howse, How To Begin To Think about the 'Democratic Deficit' at the WTO, in INTERNATIONAL ECONOMIC GOVERNANCE AND NON-ECONOMIC CONCERNS, supra note 54, at 79, 86-87.

118. See ANN FloRINI, THE COMING DEMOCRACY 87-88 (2003) (stating that the direct participation of interested people in intergovernmental organizations is a means of overcoming the principal-agent problem); Robert O. Keohane \& Joseph S. Nye Jr., The Club Model of Multilateral Cooperation and the Problems of Democratic Legitimacy, in EfFiciency, Equity, AND Legitimacy. The Multilateral Trading System at the MillenNium 264, 291 (Roger B. Porter et al. eds., 2001) (contending that the involvement of NGOs in international regimes may enhance accountability); Robert Post, Constitutional Law: The Challenge of Globalization to American Public Law Scholarship, 2 THEORETICAL INQ. L. 323, 327 (2001) (suggesting that the national frame for constitutional and administrative law may be inadequate for international organizations such as the WTO); Americo Beviglia Zampetti, Democratic Legitimacy in the World Trade Organization: The Justice Dimension, 37 J. WORLD TRADE 105, 110 (2003) (explaining that democratic legitimacy in international institutions "cannot be guaranteed only through legitimate and democratic decision-making within each participating state").

119. For recent work seeking to develop administrative law principles for the international level, see Giacinto della Cananea, Beyond the State: The Europeanization and Globalization of Procedural Administrative Law, 9 EuRoP. PuB. L. 563 (2003); Sabino Cassese, Shrimp, Turtles and Procedure: Global Standards for National Administration (2004) (unpublished manuscript on file with author). 
the international level,120 they may nevertheless help in thinking through an appropriate and effective process for international governance. ${ }^{121}$ Indeed, two different ideas-the pluralist and the civic republican-may be relevant. The pluralist will seek to open up governance and to provide opportunities for the participation of dueling interest groups in the decisionmaking process; the civic republican will seek governance decisions that relate to a public value discovered through deliberation.122 Both concepts infuse the ongoing debate about WTO transparency and participation of NGOs in the trading system. ${ }^{123}$

120. See John O. McGinnis, The Appropriate Hierarchy of Global Multilateralism and Customary International Law: The Example of the WTO, 44 VA. J. INT'L L. 229, 245-46 (2003) (stating that " $[\mathrm{b}]$ ecause democratic states can pit the views of one faction against another[,] ... they continue to provide the best mechanisms for distilling the will of peoples around the world and converting it into a world legal order"); Joseph H.H. Weiler \& Iulia Motoc, Taking Democracy Seriously; The Normative Challenge to the International Legal System, in INTERNATIONAL ECONOMIC GOVERNANCE AND Non-ECONOMIC CONCERNS, supra note 54, at 47, 70 (suggesting that "there is no demos underlying international governance"); MARTIN WOLF, WHY GLOBALIZATION WORKS 209 (2004) (stating that "the place for democratic accountability is [in] the legislatures" of WTO member governments).

121. See Jost Delbrück, Transnational Federalism: Problems and Prospects of Allocating Public Authority Beyond the State, 11 IND. J. GLOBAL LEG. STUD. 31, 54 (2004) (stating that NGOs "can play an important role as entities that promote transparency of transnational decisionmaking processes and thereby strengthen the accountability of the different public authorities").

122 See Richard J. Pierce, JR., Sidney A. Shapiro \& PAUl R. Verkuil, Administrative LAW PRocess 26-29 (4th ed. 2004) (discussing democratic theory at the national level).

123. See, e.g., Wolfgang Benedek, Relations of the WTO with Other International Organizations and NGOs, in INTERNATIONAL ECONOMIC LAW WITH A HUMAN FACE 479, 493 (Friedl Weiss et al. eds., 1998) (positing a representation function for NGOs); JAGDISH BHAGWATI, IN DEFENSE OF GLOBALIZATION 224 (2004) (stating that NGOs will often act to empower less powerful constituencies and to bring their voices into play when their votes do not accomplish this); ROBERT A. DAHL, ON DEMOCRACY 117 (1998) (doubting the possibility of a democratization of international organizations and suggesting that international decisions will be made by bargaining among elites, including nongovernmental bureaucracies); Robert Howse, The Legitimacy of the World Trade Organization, in THE LEGITIMACY OF INTERNATIONAL ORGANIZATIONS 355, 362 (Jean-Marc Coicaud et al. eds., 2001) (stating that "international civil society may underpin deliberative democracy at the [international] level"); GREGORY C. SHAFFER, DEFENDING INTERESTS (2003) (discussing transnational private sector coalitions seeking to influence national trade policy and the WTO); Daniel C. Esty, Non-governmental Organizations at the World Trade Organization: Cooperation, Competition, or Exclusion, 1 J. INT'L ECON. L. 123, 131 (1998) [hereinafter NGOs at the WTO] ("Permitting NGOs to participate in WTO discussions thus might allow the organization to hear important voices which would otherwise be unrepresented or under-represented in Geneva.") (footnote omitted); Daniel C. Esty, Linkages and Governance: NGOs at the World Trade Organization, 19 U. PA. J. INT'L ECON. L. 709, 721 (1998) (suggesting that "NGOs force government[s] . . to reassess and justify their own policy choices"); David Henderson, WTO 2002: Imaginary Crisis, Real Problems, 1 WORLD TRADE REV. 277, 285-86 (2002) (arguing that the WTO should exclude 
The traditional administrative law model fits the WTO in some respects, yet fails to fit when it comes to judicial review of WTO actions. What fits is that principals at the national level can demand that WTO-level rulemaking and adjudications be appropriately transparent and adhere to accepted norms of due process. Where a gap exists is that there is no international judicial control on the WTO as an administrative agency, and so that central dimension of administrative law is absent. This issue is not as new as it may seem. ${ }^{124}$ The idea of judicial review of the multilateral trading system was discussed in the United Nations economic negotiations of 1946-48, and a provision was included in the ITO to permit Members to ask the International Court of Justice for an advisory opinion regarding a decision by the ITO Conference of all Members. ${ }^{125}$ Because the ITO did not go into force, this provision was never used. Nevertheless, one of the U.S. negotiators, Seymour Rubin-later a highly-respected figure in the community of U.S. international lawyers126-anticipated that the "growth of international administrative agencies" would eventually draw upon legal developments at the domestic level in administrative law and

outsiders from the negotiating process so that governments can overcome protectionist interests at home); Markus Krajewski, Democratic Legitimacy and Constitutional Perspectives of WTO Law, 35 J. WORLD TRADE, February 2001, at 167, 177 (pointing out that the WTO decisionmaking process is dominated by bargaining instead of arguing); John O. McGinnis \& Mark L. Movsesian, The World Trade Constitution, 114 HARV. L. REV. 511, 571-72 (2000) (arguing that NGO access to the WTO "would undermine the key benefits of a properly constructed international trade regime[, namely] mechanisms [to] reduce the power of interest groups in order to permit trade and democracy to flourish"); Philip M. Nichols, Realism, Liberalism, Values, and the World Trade Organization, 17 U. PA. J. INT'L ECON. LAW. 851, 854-55 (1996) (criticizing study by Steve Charnovitz for not explaining why international interest groups are not already represented at the WTO through national governments); Kal Raustiala, Sovereignty and Multilateralism, 1 CHI. J. INT'L L. 401, 416 (2000) (suggesting that interest groups be allowed to follow suit as the "locus of political decision-making increasingly shifts upwards"). For one of the earliest articles on this topic see Richard Shell, The Trade Stakeholders Model and Participation by Nonstate Parties in the World Trade Organization, 17 U. PA. J. INT'L ECON. L. 359 (1996). For the debate in the broader context, see Francesca Bignami, Three Generations of Participation Rights in European Administrative Proceedings, Jean Monnet Working Paper 11/03, available at http://www.jeanmonnetprogram.org/papers/papers03.html (last visited Nov. 3, 2004) (discussing the debate about transparency and criticizing the notion of a representational role for civil society associations in European Community administration).

124. Seymour J. Rubin, The Judicial Review Problem in the International Trade Organization, 63 HARV. L. REV. 78, 79 (1949).

125. Id.; Havana Charter for an ITO, supra note 94, art. 96, para. 2. The ITO was to be bound by the Advisory Opinion. Havana Charter for an ITO, supra note 94, art. 96, para. 5.

126. Stephen M. Schwebel, Seymour J. Rubin (1914-2003), 97 AM. J. INT'L L. 310 (2003). 
judicial review. ${ }^{127}$

\section{B. Improving WTO Transparency and Participation}

The question of whether individuals and NGOs should be able to observe and participate in the WTO is highly contested. ${ }^{128}$ In my view, the position espoused in the WTO Guidelines-namely, that the participation of individuals and NGOs in trade policymaking should occur only at the national level-is undesirable on ethical as well as pragmatic grounds. Let me briefly note six reasons underlying my conclusion.

First, the notion that citizen views should be channeled only through WTO member governments disadvantages individuals who live in countries that are not democratic. ${ }^{229}$ The General Council's Guidelines suggest that the national level has the primary responsibility for taking into account the different elements of public interest which are brought to bear on trade policy-making, and yet the WTO treaty does not convey a responsibility for member governments to be democratic. 130 The Guidelines might make more sense if all WTO member governments had robust democratic accountability. Unfortunately, however, many do not. For example, Angola, Bahrain, China, Congo, Cuba, The Gambia, Haiti, Myanmar, Oman, Qatar, Rwanda, and Uganda are among WTO member countries that do not appear on Freedom House's 2003 list of electoral democracies. ${ }^{131}$ In response to this point about non-

127. Rubin, supra note 124 , at 79, 97-98.

128. See, e.g., Claude E. Barfield, Free Trade, Sovereignty, Democracy. The Future of the WORLD TRADE ORGANizATION 135-42 (2001); Kent Jones, Who's AFRAID OF THE WTO? ch. 9 (2004); Jeffrey L. Dunoff, The WTO in Transition: Of Constituents, Competence and Coherence, 33 GEO. WASH. INT'L L. REV. 979, 984-87 (2001); KENT JONES, WHO'S AFRAID OF THE WTO? ch. 9 (2004).

129. See Jeffrey Atik, Democratizing the WTO, 33 GEO. WASH. INT'L L. REV. 451, 460-61, 465, 472 (2001).

130. See WTO Agreement, supra note 58, arts. XI, para. 1, XII, para. 2; Ernst-Ulrich Petersmann, Constitutionalism and WTO Law: From a State-Centered Approach Towards a Human Rights Approach in International Economic Law, in THE POLITICAL ECONOMY OF INTERNATIONAL TRADE LAW: EsSAYS IN HONOUR OF ROBERT E. HudEC 32, 62 (Daniel L.M. Kennedy \& James D. Southwick eds., 2002) (noting that the GATT and WTO have never scrutinized the agency relationship between governments and citizens); Bruce Stokes \& Pat Choate, Democratizing U.S. Trade Policy, CounCIL ON FOREIGN RELATIONS, 2001, at 67 (noting that most WTO Members do not have full transparency, open meetings, and conflict of interest provisions back home), available

http://www.cfr.org/pub4150/bruce_stokes_pat_choate/democratizing_us_trade_policy.p hp (last visited Nov. 3, 2004).

131. FREEDOM HOUSE, EleCTORAL DEMOCRACIES, available at http://www.freedomhouse.org/research/freeworld/2003/democracies.pdf (last visited Nov. 3, 2004). See WTO, UndERSTANDING THE WTO: ThE ORGANIZATION - GEMBERS AND OBSERVERS, http://www.wto.org/english/thewto_e/whatis_e/tif_e/org6_e.htm (last visited Nov. 3, 2004), for a list of the current WTO membership. 
democratic states at the WTO, Philip Nichols has retorted that the factors that preclude constituent "participation at the national level will also preclude participation at the international level." 132 In my view, Nichols is too pessimistic on that point.

Second, the lack of openness toward NGOs disenfranchises individuals who live in countries that have not yet been allowed to join the WTO. ${ }^{133}$ For example, many people live in WTO-applicant countries such as Belarus, Ethiopia, the Russian Federation, Saudi Arabia, Sudan, Ukraine, Vietnam, and Yemen.134 None of that population has any direct representation in WTO policymaking. ${ }^{135}$ This is also true for WTO accession negotiations in which the WTO negotiates the terms for a country to join the WTO,136 without making any effort to seek the views of interested parties in that country. One wonders how the denizens of non-democratic countries feel about the WTO's disinterest in consulting them.

Third, the WTO's weaknesses in external transparency and participation are especially disabling for individuals from nonpowerful countries. Even when those countries-which tend to be in the South rather than the North-have perfect democracies, the views of citizens and constituents have to be routed to the WTO through a government which may be too weak to have its voice heard or heeded.137 In contemporary WTO practice, weak governments are often marginalized in WTO decisionmaking. 138 Thus, the current WTO system of listening to the views of NGOs only through their governments privileges citizens of rich, powerful countries. In my view, the WTO should seek to counterbalance (or at least be neutral

132. Philip M. Nichols, Extension of Standing in World Trade Organization Disputes to Nongovernment Parties, 17 U. PA. J. INT'L ECON. L. 295, 313 (1996) (discussing standing in WTO dispute settlement).

133. Individuals who live in countries that are not WTO Members have no government that can represent them at the WTO and therefore no direct way to influence the WTO or any indirect way through an NGO. See Tina Potuto Kimble, The World Trade Organization, THE FEDERALIST SOCIETY FOR LAW AND PUBLIC POLICY STUDIES, at 10, available at http://www.ngowatch.org/kimble.pdf (last visited Nov. 3, 2004) (noting that NGO seeking to influence the WTO are limited to participation through their governments).

134. For a list of applicants to the WTO, see http://www.wto.org/english/thewto_e/acc_e/acc_e.htm (last visited Nov. 3, 2004).

135. Id.

136. See WTO Agreement, supra note 58, art. XII, para. 1.

137. See Diana Tussie \& Miguel F. Lengyel, Developing Countries: Turning Participation into Influence, in DEVElopment, TRADE, AND THE WTO: A HANDBOOK ch 47 (Bernard Hoekman et al. eds., 2002).

138. Chee Yoke Ling, Democratic Governance for Sustainable Development, in TAKING LeAdership IN Global Governance IN THE CONTEXT OF Multiple ACtors AND Evolving Issues 71, 73 (Tatsuro Kunugi ed., 2004); B.S. Chimni, International Institutions Today: An Imperial Global State in the Making, 15 EUR. J. INT'L L. 1, 1920 (2004). 
to) the current assymmetries of national power, rather than reinforce those imbalances. 139

Fourth, although it is sometimes suggested that the WTO's practice of consensus decision-making ${ }^{140}$ means that individuals who can convince their own government to take a particular stance in the WTO can prevent the WTO from taking action in conflict with that stance, 141 this view leaves out the fact that an individual will not only want to prevent the WTO from doing what she perceives to be bad, but will also want to get the WTO to achieve good ends. Persuading one's own (WTO member) government is a good start to the task of convincing all 147 WTO member governments. ${ }^{142}$ The most efficient place to conduct such discourse will sometimes be at the central marketplace for trade policy, that is, at the WTO. Yet perversely, the WTO General Council continues to insist on a localization of advocacy activities despite the higher transactions costs that accrue to individuals and NGOs. ${ }^{143}$ The WTO will also be an advantageous spot for observation of the trade negotiation process. If an individual wants to monitor how well her own government is negotiating at the WTO, the best place to do that may be in Geneva, not in the national capital. ${ }^{144}$

139. See Maura Blue Jeffords, Turning the Protester into a Partner for Development: The Need for Effective Consultation Between the WTO \& NGOs, 28 BROOK. J. INT'L L. 937, 965 (2003) (suggesting that a consultative role for "NGOs can assist developing countries [sic] maximize their power"); Sylvia Ostry, World Trade Organization: Institutional Design for Better Governance, in EFFICIENCY, EQUITY, LEGITIMACY, supra note 118, at 361, 366 (noting that NGO networks are helping developing countries); Naboth van den Broek, Power Paradoxes in Enforcement and Implementation of World Trade Organization Dispute Settlement Reports: Interdisciplinary Approaches and New Proposals, 37 J. WORLD TRADE 127, 160 (2003) (suggesting that greater WTO transparency and a role for NGOs could help smaller countries). But see Maki Tanaka, Bridging the Gap Between Northern NGOs and Southern Sovereigns in the Trade-Environment Debate: The Pursuit of Democratic Dispute Settlements in the WTO Under the Rio Principles, 30 ECOLOGY L.Q. 113, 14344 (2003) (arguing that southern NGOs are generally disinterested in promoting direct NGO participation in the WTO because that would favor Northern NGOs).

140. WTO Agreement, supra note 58, art. IX, para. 1.

141. See, e.g., Andrew T. Guzman, Global Governance and the WTO, 45 HARV. INT'L L.J. 303, 338 (2004) ("States need not worry that policies will be forced upon them. To the extent that national decision makers are democratically accountable, therefore, they serve as guardians of the interests of their citizens.").

142 See PETER Singer, ONE World 75 (2nd ed. 2002) (criticizing the WTO website for saying that consensus decision-making is more democratic than majority rule and explaining that consensus decision-making favors the status quo).

143. See NGO Guidelines, supra note 96. Higher transaction costs are likely to ensue when an NGO from WTO Member $\mathrm{N}_{1}$ has to devise lobbying strategies for decentralized lobbying in Members $\mathrm{N}_{1}$ to $\mathrm{N}_{148}$ rather than at the WTO headquarters in Geneva.

144. See Howse, supra note 117, at 89 (stating that the presence of NGO monitoring at the level of negotiations can help to reduce agency costs). 
Fifth, by conceptualizing the trade debate as being decentered within national units, the WTO reinforces the tendencies of economic nationalism to dominate trade policy. ${ }^{145}$ The "different elements of public interest which are brought to bear on trade policy-making" at the national level tend to be dominated by the financial interests of import-competing industries.146 Other elements of the public interest-including volitions for free trade, environmental protection or the alleviation of world poverty-may be disadvantaged in a debate that is purposefully segmented by homeland.

Furthermore, the attitude reflected in the WTO's NGO Guidelines seems to assume that the trade debate at the national level should funnel in only internal views, and that WTO itself should refuse to hear views not pronounced by a government. ${ }^{147}$ Yet that attitude takes away the voice of transnational associations. 148 Such a parochial stance is ironic. Back in 1923, participation by the International Chamber of Commerce was appropriate to help governments draft the transparency principles in the Customs Convention, and now eight decades later, in a far more globalized world, the WTO will not allow NGOs like the International Chamber of Commerce, Transparency International, or Oxfam to be directly

145. See Judith Goldstein, International Institutions and Domestic Politics: GATT, WTO, and the Liberalization of International Trade, in THE WTO AS AN INTERNATIONAL ORGANIZATION 133, 138-51 (Anne O. Krueger ed. 1998) (discussing the role of international trade institutions in moderating domestic trade policy).

146. See NGO Guidelines, supra note 96; JAGDISH BHAGWATI, PROTECTIONISM 71-73 (1989).

147. See WTO Secretariat, WTO Policy Issues for Parliamentarians: A Guide to Current Trade Issues for Legislators, 2001, available at http://www.wto.org/english/res_e/booksp_e/parliamentarians_e.pdf (last visited Nov. 3, 2004). The Guide states:

Some form of parliamentary assembly represents citizens under most constitutions. That is where citizens need to exercise their democratic rights.

... Only governments can negotiate trade rules for countries. Citizens are expected to be represented at the WTO through their governments.

$\ldots$

... WTO Members have explained often that governments are the ones which represent the interests of all their respective citizens.

$\cdots$

... Member governments have repeatedly re-affirmed that they consider themselves responsible for dialogue with their citizens and for determining how best to represent the interests of their countries. Id. at $13-16$.

148. August Reinisch \& Christina Irgel, The Participation of Non-Governmental Organisations (NGOs) in WTO Dispute Settlement System, 1 Non-STATE ACTORS \& INT'L L. 127, 132 (2001) (noting the increase in transnational actors which are unlikely to be represented by any national government). 
involved in the work of the WTO or its meetings. ${ }^{149}$

Sixth, the resistance of the WTO to providing opportunities for a dialogue with nongovernmental actors reduces the competition of ideas and reinforces status quo thinking. ${ }^{150}$ The insulated status quo may be trade-centric and market-based, or it may be mercantilist and pro-producer. Regardless of what values dominate on a particular issue, the debate within the WTO can be truncated because of limited voices and the lack of an interplay of ideas. To be sure, there is a robust debate about trade and its implications in Geneva and throughout the world. Nevertheless, it seems unlikely that all of the best ideas for trade policymaking get communicated and vetted in the rarified atmosphere at the WTO.151 From a civic republican perspective, enhancing nongovernmental participation may engender more deliberative decisionmaking at the WTO. ${ }^{152}$

In summary, the WTO continues to make progress toward full transparency, but has stalled in effecting opportunities for constructive participation by NGOs and the private sector. Although this situation is often criticized, few analysts have made the further point that the WTO's insularity contradicts its promotion of participation in the trade law administration of WTO member governments. Sooner or later, the normative dissonance involved in going in two directions at once will force a reassessment at the WTO. My hope and expectation is that the WTO will revise its internal rules to provide meaningful opportunities for public participation and to promote procedural fairness and regularity as a means of enhancing accountability and legitimacy. In doing so, the WTO can

149. On the role of Transparency International, see Fredrik Galtung, A Global Network to Curb Corruption: The Experience of Transparency International, in THE Third Force: The RIse of Transnational Civil Society 17 (Ann M. Florini ed., 2000). On the role of Oxfam, see CRAIG WARKENTIN, REshaping WoRLD POLITICS 116-27 (2001). See also Sean D. Murphy, Biotechnology and International Law, 42 HARV. INT'L L.J. 47, 105 (2001) (suggesting that transnational NGOs transform the two-level game into a multi-level game); Robert D. Putnam, Diplomacy and Domestic Politics: The Logic of Two-Level Games, 42 INT'L ORG. 427, 434 (1998) (framing the analogy of the two-level game).

150. NGOs at the WTO, supra note 123 , at 135-37.

151. See José E. Alvarez, The WTO as Linkage Machine, 96 AM. J. INT'L L. 146, 151 (2002) (suggesting that trade insiders may recommend similar but inappropriate solutions for problems).

152 Cf. Robert O. Keohane, Governance in a Partially Globalized World, in Governing Globalization: Power, Authority AND Global Governance 325, 343 (David Held \& Anthony McGrew eds., 2002) (suggesting that international institutions be designed so that persuasion, not merely interests and bargaining, plays an important role); MARY KALDOR, GLOBAL CIVIL SOCIETY: AN ANSWER TO WAR 148 (2003) (stating that global civil society offers a possibility for the voices, if not the votes, of the victims of globalization to be heard); Marco Verweij \& Timothy E. Josling, Special Issue: Deliberately Democratizing Multilateral Organization, 16 GOVERNANCE 1 (2003) (noting the important role of deliberation). 
be aided by insights drawn from the field of administrative law.153 The coming challenge will be to fruitfully transplant principles developed for a national context to the WTO.154

\section{FUTURE STEPS FOR THE WTO}

Part III presents several proposals for how the WTO can do more to enhance transparency and participation both at the national level and at the WTO. Section A addresses the national level and Section B addresses improvements needed inside the WTO.

\section{A. National Level}

The most obvious future direction for WTO negotiations is to strengthen the obligations in WTO agreements for domestic transparency and participation at the national level. Unfortunately, very little of this will be accomplished in the current WTO negotiating round. The major issue that had been on the table was transparency in government procurement, but in August 2004, the WTO General Council decided to drop that issue from the negotiations. ${ }^{155}$

Besides the procedural dimension of national transparency, there is also a substantive dimension, and it would still be possible for WTO negotiations to make progress in that area. By a substantive dimension, I mean attention to government restrictions on the inward flow of information. One serious problem today is that some governments, such as China, restrict transborder trade in informational services provided through the internet.156 Such restrictions should be attacked in ongoing GATS negotiations.

\section{B. Improvements Inside the WTO}

Section B offers proposals in four areas: (1) negotiations,

153. Daniel C. Esty, Linkages and Governance: NGOs at the World Trade Organization, 19 U. PA. J. INT'L ECON. L. 709, 728 (1998) (calling for the WTO to create a body of administrative rules and procedures and to adhere to principles of administrative law).

154. See Jonathan B. Wiener, Something Borrowed for Something Blue: Legal Transplants and the Evolution of Global Environmental Law, 27 ECOLOGY L.Q. 1295 (2001) (discussing vertical borrowing from national to international law).

155. Doha Work Programme, Decision Adopted by the General Council on 1 August 2004, WT/L/579, $\quad$ para. 1(g) (Aug. $2, \quad 2004$ ), http://www.wto.org/english/tratop_e/dda_e/ddadraft_31jul04_e.pdf (last visited Nov. 3, 2004). The Doha Ministerial Declaration had noted the possibility of clarifications or improvements to GATT Article X. Ministerial Declaration, WT/MIN(01)DEC/1, para. $27 \quad$ (Nov. 20, 2001), http://www.wto.org/english/thewto_e/minist_e/min01_e/mindecl_e.doc (last visited Nov. 3, 2004).

156. Charles Hutzler, China Finds New Ways to Restrict Access to the Internet, WALL ST. J., Sept. 1, 2004, at B1. 
rulemaking, (3) dispute settlement, and (4) parliamentary input.

\section{Negotiations}

The transparency of WTO negotiations continues to improve. Before and during the 2001 Ministerial Conference in Doha and the 2003 Ministerial Conference in Cancún, the WTO did not release any of the draft negotiating texts to the public. This gap in information made it difficult for the interested public to follow what was happening in the negotiations and to influence them. WTO opaqueness also occurred with respect to the draft negotiating text on the issue of the compulsory licensing of drugs. The so-called "Motta Text" of December 16, 2002 was never posted on the WTO website. ${ }^{157}$ Yet in the most recent trade negotiations, the WTO has moved away from these restrictive practices. In the days leading up to the August 2004 decision, ${ }^{158}$ the WTO Secretariat posted the draft texts. 159

By contrast, the WTO has not made improvements in participatory opportunities in the various WTO committees, bodies, councils, etc. 160 No modalities exist for the public to offer comments to negotiators as to how the Doha Round objectives might be achieved. ${ }^{161}$ The WTO's obstinacy can be contrasted to the openness shown in the negotiations for the Free Trade Area of the Americas, where the governments have set up a Civil Society Committee, which issued an "Open and Ongoing Invitation" for civil society to provide written contributions to the governments. ${ }^{162}$ All (or nearly all) of the comments received since 2000 are posted on the FTAA website. ${ }^{163} \mathrm{In}$

157. See Daniel Pruzin, U.S. Seen Losing Ground in Latest Draft of Reform Proposal on TRIPs / Medicines, DAILY REP. FOR EXECUTIVES (BNA), Dec. 17, 2002, at A8 (discussing Motta draft text).

158. See Breakthrough on Trade, N.Y. TIMES, Aug. 3, 2004, at A-18.

159. WTO News, First Draft Discussed as Chairs Warn of 30 July 'Drop Dead' Deadline (July 20, 2004), http://www.wto.org/english/news_e/news04_e/dda_package_sum_19_20july04_e.htm (last visited Nov. 3, 2004); WTO News, Members Comment on New Draft as Chair Warns of Overload (July 30, 2004), http://www.wto.org/english/news_e/news04_e/dda_package_sum_30july04_e.htm (last visited Nov. 3, 2004). Both of these news releases contained links to the draft WTO negotiating texts.

160. See supra Part II.

161. See supra Part II.

162 See OPEN AND ONGOING INVITATION to Civil SOCIETY IN FTAA PARTICIPATING COUNTRIES, FTAA COMMITTEE ON GOVERNMENT REPRESENTATIVES ON THE PARTICIPATION OF CIVIL SOCIETY (Mar. 31, 2004), available at http://www.ftaaalca.org/spcomm/SOC/INVITATION/SOC15r5_e.asp (last visited Nov. 3, 2004); see also Eric Dannenmaier, Trade, Democracy, and the FTAA: Public Access to the Process of Constructing a Free Trade Area of the Americas, 27 FoRDHAM INT'L L.J. 1066 (2004).

163. See http://www.ftaa-alca.org/SPCOMM/COMMCS_E.ASP (last visited Nov. 3, 2004). 
my view, the WTO should follow this enlightened practice from the Americas.

\section{Rulemaking}

WTO entities have also refused to solicit public comments in ongoing rulemaking functions. For example, in April 2004, the WTO Appellate Body circulated a set of draft amendments to its Working Procedures and invited member governments to submit comments. 164 The Appellate Body, however, did not ask for comments from the public or from private attorneys that regularly practice before it in representing governments. ${ }^{165}$ In 2000, the WTO's TBT Committee enacted a decision on "Principles for the Development of International Standards." 166 Despite the implications of this decision for activities outside the WTO, the TBT Committee did not seek public comments.

The WTO's hidebound attitude about participation differs from that of some other international organizations that have embraced new e-government technologies to seek input from the public. For example, the Organisation for Economic Co-operation and Development (OECD), the United Nations Framework Convention on Climate Change's Clean Development Mechanism, the InterAmerican Development Bank, and the North American Commission on Environmental Cooperation have begun to seek public comments on new proposals. 167 As more international organizations follow,

164. Proposed Amendments to the Working Procedures for Appellate Review, Communication from the Appellate Review, WT/AB/WP/8 (Apr. 8, 2004), http://docsonline.wto.org/gen_home.asp?language $=1 \&_{-}=1$ (last visited Nov. 3, 2004) (One can find this document by selecting simple search and inputting "WT/AB/WP/8" in the "Document symbol" field.). The new Working Procedures were finalized in October. Working Procedures for Appellate Review, Communication from the $\begin{array}{lllll}\text { Appellate } & \text { Review, } & \text { WT/AB/WP/W/9 } & \text { (Oct. } & 7,\end{array}$ http://www.wto.org/english/tratop_e/dispu_e/wpw9_e.doc (last visited Nov. 3, 2004) [hereinafter Working Procedures for the Appellate Review].

165. See Working Procedures for the Appellate Review, supra note 164.

166. Decisions and Recommendations Adopted by the Committee Since 1 January 1995, Committee on Technical Barriers to Trade, G/TBT/1/Rev.8, part. IX (May 23, 2002), http://www.wto.org/english/tratop_e/tbt_e/tbt_e.htm (last visited Nov. 3, 2004).

167. See, e.g., OECD Invites Comments on Draft Revision of its Corporate Governance Principles, Jan. 12, 2004 (no longer available online, on file with author); United Nations Framework CONVEntion ON Climate Change, Clean Development Mechanism, Opening of Public Comments Period on CDM-PDD at VALIDATION STAGE, http://cdm.unfccc.int/CDMNews/issues/issues/I137_7992737/viewnewsitem.html (last visited Nov. 3, 2004); INTER-AMERICAN DEVELOPMENT, We WANT Your OPINION: Public CONSUltation ON IDB Strategies AND Policies, http://www.iadb.org/aboutus/iii/public_consultation.cfm (last visited Nov. 3, 2004); NORTH AMERICAN COMMISSION FOR ENVIRONMENTAL COOPERATION, CEC INVITES PUBLIC COMMENT ON DRAFT DOCUMENT: FUTURE DIRECTIONS UNDER THE COMMISSION For EnVIRonmental CoOperation Sound MANagement of Chemicals Initiative 
there will be a greater need for a "Global Register" to announce opportunities for public comment.168 There will also need to be efficient mechanisms for reading and analyzing public comments to international organizations as the number of comments increases.

\section{Dispute Settlement}

The benefits of greater transparency are especially compelling for WTO dispute settlement, the one area of WTO law where nonconsensus decisionmaking is imposed. In the eyes of many observers, however, the non-transparency required by WTO dispute rules has served to undermine the legitimacy of panel and Appellate Body decisions. ${ }^{169}$ Recently, the U.S. government sought to open up panel hearings in the Biotech Products case, but the other complaining parties refused to go along. ${ }^{170}$ The U.S. government has been more successful in bilateral free trade negotiations, where its prospective trading partners have agreed to transparency in dispute panels. For example, the U.S.-Morocco Free Trade Agreement states that parties have "a right to at least one hearing before the panel and that [any] . . . such hearing[s] shall be open to the public." 171

A body of analysis already exists about the limited progress made by WTO panels and the Appellate Body in accepting amicus curiae briefs, 172 and so that situation will not be reviewed here except

(Apr. $\quad 14, \quad$ 2004) available at

http://www.cec.org/news/details/index.cfm?varlan=english\&ID=2605 (last visited Nov. $3,2004)$.

168. See Steve Charnovitz, Economic and Social Actors in the World Trade Organization, 7 ILSA J. INT'L \& COMP. L. 259, 274 (2001) (calling attention to the trend in international organizations of soliciting public comments and proposing a Global Federal Register).

169. See, e.g., Claus-Dieter Ehlermann, Reflections on the Process of Clarification and Improvement of the DSU, in THE WTO DisPUTE SETTLEMENT SYSTEM 1995-2003 105, 110 (Federico Ortino et al. eds., 2004) (stating that increased transparency will enhance the legitimacy of the dispute settlement process); Lacarte, supra note 81, at 684 (suggesting open hearings for panels and the Appellate Body); Donald McRae, What is the Future of WTO Dispute Settlement?, 7 J. INT'L ECON. L. 3, 17 (2004) (stating that the failure to open panel and Appellate Body hearings to the public and to allow public access to the pleadings of the parties undermines the legitimacy of the system). Ehlermann and Lacarte were members of the Appellate Body; McRae has served as a WTO panelist.

170. Daniel Pruzin, U.S. Fails in Campaign to Open Up WTO GMO Panel Proceedings to Public, DAILY REP. FOR EXECUTIVES (BNA), May 5, 2004, at A-1.

171. U.S.-Morocco Free Trade Agreement, art. 20.8(1)(a), June 15, 2004, available at http://www.ustr.gov/Trade_Agreements/Bilateral/Morocco_FTA/FInal_Text/Section_In dex.html (last visited Nov. 3, 2004).

172 See, e.g., Jared B. Cawley, Friend of the Court: How the WTO Justifies the Acceptance of the Amicus Curiae Brief from Non-Governmental Organizations, 23 Penn. St. InT'L L. Rev. 47 (2004); Jeffrey L. Dunoff, The WTO's Legitimacy Crisis: Reflections on the Law and Politics of WTO Dispute Resolution, 13 AM. REV. INT'L ARB. 197, 199-205 (2002); Duncan B. Hollis, Private Actors in Public International 
to make one point. The Appellate Body ought to be more transparent about what it learns from amicus briefs. For example in the Softwood Lumber Final Determination decision in 2004, the Appellate Body reported that it had received a brief from the Indigenous Network on Economies and Trade and a joint brief from Defenders of Wildlife, the Natural Resources Defense Council, and the Northwest Ecosystem Alliance. ${ }^{173}$ Without revealing the content of the briefs, the Appellate Body then stated that it did not find it necessary to take the two amicus curiae briefs into account in rendering its decision. ${ }^{174}$ In a situation like that, the interested public understandably has a hard time knowing whether the Appellate Body's reasoning and conclusion would have benefited from taking the briefs into account. My recommendation is for the Appellate Body to post on its webpage each amicus brief that it receives.

\section{A Parliamentary Body}

In recent years, parliamentarians from many countries have held occasional interparliamentary conferences to discuss the WTO. ${ }^{175}$ The most recent conference was held in September 2003 alongside the WTO Ministerial Conference in Cancún, where delegates from seventy national parliaments and five regional parliaments participated.176 The declaration adopted by the parliamentarians called for a "parliamentary dimension to international trade negotiations and arrangements."177 Although about thirty members of the U.S. Congress made the journey to

Law: Amicus Curiae and the Case for the Retention of State Sovereignty, 25 B.C. INT'L \& COMP. L. REv. 235, 238-42 (2002); Robert E. Hudec, Free Trade, Sovereignty, Democracy: The Future of the World Trade Organization, 1 WORLD TRADE REV. 211, 217 (2002) (characterizing the decision to permit amicus brief as a judicial mistake); Jacqueline Peel, Giving the Public a Voice in the Protection of the Global Environment: Avenues for Participation by NGOs in Dispute Resolution at the European Court of Justice and World Trade Organization, 12 CoLO. J. INT'L ENVTL. L \& POL'Y 47, 69-70 (2001) (fearing that businesses will participate more than public interest groups); Cesare P.R. Romano, The Americanization of International Litigation, 19 OHIO. ST. L. J. ON DisP. Resol. 89, 105-09 (2003); Brigitte Stern, Private Entities and the WTO Dispute Settlement Mechanism, in THE WORLD TRADE ORganization: Legal, ECONOMic AND Political ANAlysis (Patrick F. J. Macrory, Arthur E. Appleton, and Michael G. Plummer eds., Springer, forthcoming 2005) (manuscript on file with author).

173. Softwood Lumber Final Determination, supra note 92, para. 9.

174 Id.

175. Erika Mann, A Parliamentary Dimension to the WTO - More Than Just A Vision?!, 7 J. INT'L ECON. L. 659, 662-63 (2004).

176. See Cancun Session of the Parliamentary Conference on the WTO, InterParliamentary Union \& European Parliament (Sept. 9 \& 12, 2003), http://www.ipu.org/splz\%2De/cancun.htm (last visited Nov. 3, 2004).

177. Id. para. 14 . 
Cancún, none of them participated in the inter-parliamentary conference.178 Based on interviews, Gregory Shaffer concluded that "[t]he US government and US Congress generally are not supportive of global inter-parliamentarian meetings." 179 In my view, this attitude by the U.S. Congress is short-sighted and misses an opportunity for elected officials to learn from other parliaments. Recently, David Skaggs, a former member of the U.S. House of Representatives, suggested that "an increased role for national parliamentarians and Congresspersons and for national and international NGOs should have a direct bearing on the public's sense of the WTO system's legitimacy and trustworthiness." 180

\section{CONCLUSION}

The WTO continues to be criticized by friends and foes for its penchant for secrecy and its resistance to more open, inclusive participatory practices. Moreover, the friends point out how the WTO's closed doors give traction to the foes of world trade order. Eventually, WTO member governments will reach a consensus that reforms are needed. ${ }^{181}$ In my view, the sooner the better.

In this article, I make the case for rewriting the 1996 NGO Guidelines ${ }^{182}$ so as to provide meaningful opportunities for nongovernmental participation in WTO operations. The article describes the historical roots of the trade transparency norm, analyzes the WTO text and related judicial interpretations, and then seeks to show that the norms for national trade administration should be honored by the WTO. While I do not contend that the connection between national trade and international trade law is seamless, I do contend that the administrative law principles applicable to a national government are relevant to rulemaking and adjudication in international organizations. ${ }^{183}$ As citizens of a nation and denizens of the world, our aspirations for good governance cannot be cabined within the nation-state.

178. Gregory Shaffer, Parliamentary Oversight of WTO Rule-Making: The Political, Normative, and Practical Contexts, 7 J. INT'L ECON. L. 629, 641 (2004).

179. Id. at 642 .

180. David E. Skaggs, How Can Parliamentary Participation in WTO Rule-Making and Democratic Control Be Made More Effective in the WTO?: A United States Congressional Perspective, 7 J. INT'L ECON. L. 655, 657 (2004).

181. Recently, the U.N. Conference on Trade and Development (UNCTAD) recommended, inter alia, that UNCTAD should make participation of civil society and the private sector in its work more systematic in order to enhance the valueadded from that cooperation. São Paulo Consensus, U.N. Conference on Trade and Development, 11th Sess., para. 115, U.N. Doc. TD/410 (2004), http://www.unctad.org/en/docs/td410_en.pdf (last visited Nov. 3, 2004).

182 See text accompanying supra note 97.

183. See Rubin, supra note 124, at 98 (denoting the field of international administrative law). 
